\title{
Contrasts in the movements and habitat use of juvenile and adult white sharks (Carcharodon carcharias) at Guadalupe Island, Mexico
}

\author{
E. Mauricio Hoyos-Padilla ${ }^{1,2}$, A. Peter Klimley ${ }^{3}$, Felipe Galván-Magaña ${ }^{4 *}$ and Alex Antoniou ${ }^{2}$
}

\begin{abstract}
Background: Although the effort in the study of white sharks in Mexico is rapidly elucidating adult biology, almost nothing is known about the juveniles. Current understanding of this life history is based largely on the incidental take of juveniles in nursery grounds in the Pacific coast of Baja California and some individuals tagged in the USA that have migrated to Mexican waters. Also, it is not known how or when they recruit to adult aggregation sites or how they learn to make seasonal migrations offshore. Five white sharks were manually tracked using ultrasonic transmitters with depth and temperature sensors between 2006 and 2007. Additional white sharks were tagged $(N=60)$ with long-lived coded transmitters and detected at listening stations located on the west coast of the United States of America and Guadalupe Island (GI) from August 2008 to October 2015.
\end{abstract}

Results: We found that: (1) juvenile white sharks remained close to the island throughout the day between the surface and $50 \mathrm{~m}$ depth in warm waters (from 14 to $20^{\circ} \mathrm{C}$ ), whereas the adults moved offshore into deep waters during the day and stayed close to the island during the night presenting a broader tolerance of colder waters (from 9 to $\left.20^{\circ} \mathrm{C}\right) ;(2)$ tagged white sharks had a positive correlation between total length and habitat range, and the core areas of adults were related to pinniped colonies; (3) adults patrolled in deep waters in November and December when the northern elephant seals (NESs) returned back to the island for pupping with their mean mass higher than during the winter post-breeding migration; (4) tagged juvenile white sharks remained near the island for 12-14 months before departing; and (5) tagged subadults undertook coastal migrations before starting their offshore migrations.

Conclusions: The data collected in our study suggest that white shark juveniles arrive to Gl from nursery grounds on the mainland after they have reached at least $180 \mathrm{~cm} \mathrm{TL}$; then, they remained around the island for several months, potentially taking advantage of the diversity of prey. In addition, they may start their first offshore migrations, coming back to their nursery grounds and Gl before they reach maturity, while at Gl juveniles stayed close to the shore and in shallow water to avoid adults, probably feeding on demersal prey and species that perform nocturnal migrations such as squid and mackerel. It is argued that the distribution of the large white sharks in Gl is controlled by the availability of NES and that adult white sharks look for this prey in deep waters during the day in the vicinity of the seal colonies, taking advantage of the great visibility of GI waters. It is also possible that white sharks take advantage of NES in Gl before they go to their pupping grounds to give birth in California and Baja California or to their offshore migration to the west.

Keywords: Movements, Seasonality, Nursery ground, Telemetry, Predation, Guadalupe Island

\footnotetext{
*Correspondence: galvan.felipe@gmail.com

${ }^{4}$ Instituto Politécnico Nacional, Centro Interdisciplinario de Ciencias

Marinas (CICIMAR), Av. IPN s/n, C.P. 23096 La Paz, B.C.S., Mexico

Full list of author information is available at the end of the article
} 


\section{Background}

Little is known about the ecology, population biology, movement patterns, and migrations of white sharks off the coast of Mexico. White sharks are occasionally seen and/or captured in the Gulf of California [1] and are mainly known from Cedros Island, San Benito Island, and GI off the coast of the Baja Peninsula [2,3]. The latter has been considered one of the most important white shark aggregation sites in the eastern Pacific. White sharks are present at GI between the months of July to January, with peak months for aggregations between August and December. The individuals at this site can be reliably identified, and the same sharks have been found to return to the site year after year [4]. According to previous authors, the white sharks at this site varied in total length (TL) from 2.5 to $5.5 \mathrm{~m}$, and most were $>3.5 \mathrm{~m}$ in length.

There are observable differences between juvenile and adult white sharks. They vary greatly in their anatomy, diet, and habitat use in most regions of the world. The dental morphology of juveniles differs from adult white sharks, and the transition is complete in individuals around $3.8 \mathrm{~m}$ TL [5]. Juvenile white sharks have a subterminal mouth with pointed teeth in their jaws for seizing crustaceans and fish near the bottom and swallowing them whole. Adults have a more terminal mouth with serrated triangulated teeth for seizing seals and sea lions, removing large amounts of fat and muscle and releasing them to consume them by multiple bites [6, 7]. For many species, preferred habitats and spatial dynamics vary over their life history, and these differences may have ramifications for threat assessment and conservation actions during different life-history stages [8]. Given the considerable shift in diet, thermal capabilities and preferred habitat, we should expect that juvenile and adult white sharks may have different distributions and present different seasonality, and this would be reflected in different vertical and horizontal movements and occurrence on GI between the life-history classes.

Using ultrasonic telemetry to track white sharks, we were able to describe what we believe is a differential use of the island by the different life-history stages and document the connectivity between GI and the west coast of the USA. In addition, we provide evidence of the presence of juvenile white sharks and that the use of GI by this stage is more important than that it was previously believed. This information is essential for assessing the importance of different habitats to the species, linkages between areas where juvenile white sharks have been encountered, and potential sources of threat, especially pressure from sectors wishing to pursue an ecotourismtype experience through cage diving or baiting sharks.

\section{Methods}

\section{Study site}

Guadalupe Island $\left(29^{\circ} 00^{\prime} \mathrm{N}, 118^{\circ} 26^{\prime} \mathrm{W}\right)$, with a $250 \mathrm{~km}^{2}$ area, is $240 \mathrm{~km}$ offshore of the Baja California Peninsula (Fig. 1a) and lies within the California Current System. The surrounding waters have an average sea surface temperature of $18{ }^{\circ} \mathrm{C}$, ranging from $16{ }^{\circ} \mathrm{C}$ in the spring to $20{ }^{\circ} \mathrm{C}$ in the summer. The island is surrounded by a narrow shelf with the exception of the southern tip, where the shelf extends away from the island with depths of $200 \mathrm{~m}$ between GI and its closest island, Inner Islet, and farthest, Outer Islet (Fig. 1b). The offshore waters reach depths of $3600 \mathrm{~m}[9]$.

\section{Telemetry}

Before tagging, sex and conspicuous characteristics of each individual were determined using underwater video images of the sharks. Total length was estimated from the length of the shark relative to the length of the vessel. We use the following life-history definitions for white sharks: young-of-the-year (YOY) sharks $(\leq 1.75 \mathrm{~cm} \mathrm{TL}$ ), juvenile ( $>1.75-3.0)$, subadult $(>3-3.6 \mathrm{~m}$ TL for males and $>3-$ $4.8 \mathrm{~m}$ TL for females), and adults ( $>3.6 \mathrm{~m}$ TL for males and $>4.8 \mathrm{~m}$ TL for females) [8].

\section{Continuous tracking}

Five white sharks were fitted with external ultrasonic transmitters $(120 \mathrm{~mm}$ long, $22 \mathrm{~mm}$ diameter, and $35 \mathrm{~g}$ weight in water; V22-TP-5XS-EP, Vemco, Ltd.) from the boat using pole spears to affix a stainless steel dart to the dorsal musculature of the shark with a tether attaching the dart to the transmitter. The sharks were tracked during November and December of 2006 as well as October and November of 2007. The transmitters were equipped with temperature $\left(10-40{ }^{\circ} \mathrm{C}\right)$ and pressure sensors $(0-340 \mathrm{~m})$ that transmit data at $69 \mathrm{kHz}$ and had a nominal life span of 10 days. To determine whether one adult was feeding on seals, a transmitter (V16TP-3x, Vemco, Ltd) with a temperature sensor $\left(10-40^{\circ} \mathrm{C}\right)$ was implanted within the stomach in order to detect the rise in stomach temperature associated with swallowing warm-bodied mammals [10]. The attachment method consisted of inducing the shark to swallow a piece of bait with a transmitter hidden inside. We carried out shipboard tracking from a skiff outfitted with a VH110 directional hydrophone mounted on the side of the boat hull and a VR100 receiver to detect the data transmitted from each shark. The receiver recorded depth and temperature from the transmitter, and latitude and longitude of the boat trajectory with a GPS. We tagged and tracked (White Shark Manually Tracked $=$ WSMT) the following sharks: two male juveniles (WSMT 1 and WSMT 3), one male adult 

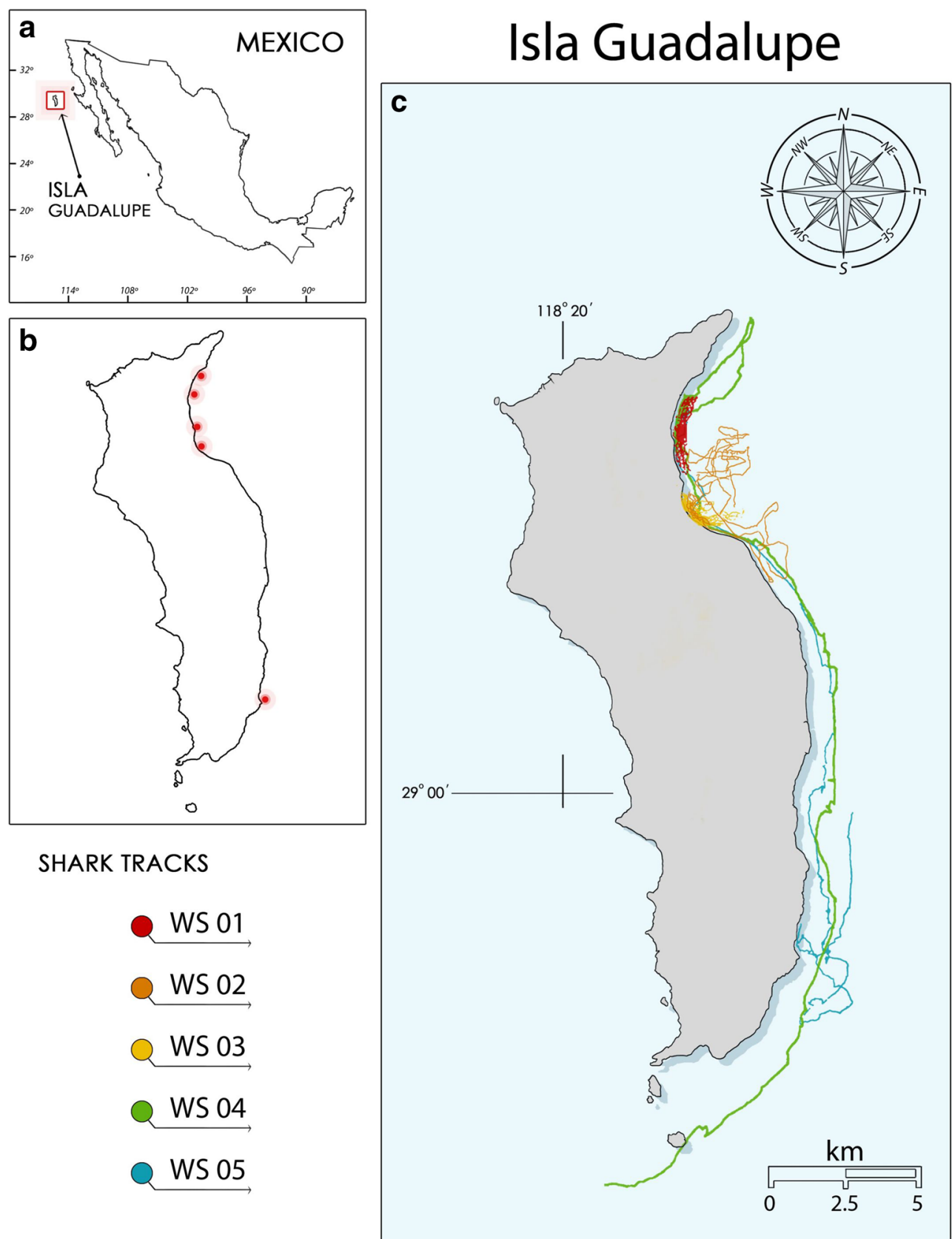

SHARK TRACKS

WS 01

WS 02

WS 03

WS 04

WS 05

Fig. 1 Map of Guadalupe Island (a), locations of the five underwater receivers (red circles) (b), and tracks of two juvenile and three adult white $\operatorname{sharks}(\mathbf{c})$

(WSMT 4), and one subadult and one adult females (WSMT 2 and WSMT 5) (Table 1). The internal transmitter with a temperature sensor was placed on WSMT 2 to infer predation.

\section{Long-term monitoring}

We attached coded ultrasonic transmitters (V16-6x, frequency $69 \mathrm{kHz}$, power $6 \mathrm{H}$, nominal delay $90-180 \mathrm{~s}$, life
1364 days, Vemco Ltd.) to 60 white sharks at the island (Table 2). Transmitters were deployed during eight expeditions carried out from August to December for each of the seven seasons from 2008 to 2014. The transmitters were affixed to the sharks by inserting a stainless steel dart in the dorsal musculature behind the first dorsal fin by free diving or from the boat using a pole spear. An array of five tag-detecting receivers (Vemco VR2, Ltd.) 
Table 1 Sharks manually tracked in Guadalupe Island during 2006 and 2007

\begin{tabular}{llllllll}
\hline ID & TL $(\mathbf{c m})$ & Sex & Tracking period & Duration $(\mathbf{h}: \mathbf{m})$ & Distance $(\mathbf{k m})$ & Mean depth $(\mathbf{m})$ & Max depth $(\mathbf{m})$ \\
\hline WSMT 1 & 300 & M & November 10-December 3, 2006 & $65: 19$ & 116.7 & 31.6 & 140.1 \\
WSMT 2 & 450 & F & November 23-December 9, 2006 & $44: 03$ & 129.2 & 108.4 & 219 \\
WSMT 3 & 180 & M & October 3-8, 2007 & $40: 58$ & 75.1 & 33 & 92.4 \\
WSMT 4 & 450 & M & November 3-4, 2007 & $20: 14$ & 66.4 & 60.1 & 314.2 \\
WSMT 5 & 500 & F & November 10-11, 2007 & $23: 36$ & 69.5 & 100 & 339.5 \\
\hline
\end{tabular}

Sex: $M$ Male, $F$ Female, Duration: $h$ hours; $m$ minutes

or listening stations was deployed at the east coast of the island near the pinniped colonies (Fig. 1b).

The 60 white sharks consisted of 14 juveniles (10 males and 4 females), 21 subadults ( 7 males and 14 females), and 25 adults (15 males and 10 females) (Table 2). The white sharks detected by receivers installed in the USA are part of a large array of listening stations deployed and maintained by a network of researchers we are collaborating with.

\section{Data analyses}

We chose an interval of 7 min between positions for calculating the headings of each shark that was manually tracked [11]. The files were imported into a geographic information system (ESRI, Arc View 3.2) and were compared against correlated random walks using the site fidelity test in the Animal Movement 2.0 extension for ArcView [12]. If the preliminary data analysis indicates that site fidelity exists, the next step is to determine the animal's home range. Animal Movement implements a fixed kernel analysis with the smoothing factor calculated via leastsquare cross-validation (LSCV), for ascertaining home range [13]. When choosing output contours, it is heuristically useful to consider the $95 \%$ contour as that area the animal actually uses and the $50 \%$ contour as the core area of activity. Statistical comparisons (linear regression) between individuals were made with the $50 \%$ contour, as it is less affected by deviations from the assumptions of the home range models [12]. To measure the distances travelled, we used the extension Geoprocessing and Spatial Analyst from Arc GIS, with the Euclidean Distance tool (measures straight-line distance from each cell to the closest source). Vertical movement patterns and temperature preferences were analyzed for mean differences using a two-sample $t$ test. The sunrise and sunset were determined with the NOAA Solar Calculator (http://www.srrb.noaa. gov/highlights/sunrise/sunrise.html).

\section{Results}

\section{Horizontal movements}

The juveniles (WSMT 1 and WSMT 3) remained close to the shore. For most of the time, they remained less than $100 \mathrm{~m}$ from shore (Fig. 1C). They swam north and south parallel to the coast in the northeast bay of the island. They swam shorter distances than adults (in a 24-h period), 45.7 and $40.6 \mathrm{~km}$, respectively, and exhibited neither significant dispersion nor significant linearity in their movements. Spatial use analysis indicated that the core use region of WSMT 1 was $0.29 \mathrm{~km}^{2}$ and for WSMT 3 was $0.17 \mathrm{~km}^{2}$ in front of Twin Canyons (Fig. 1b), in the southern region of the northeast bay of GI (Fig. 2a, b).

The adults moved over greater distances than juveniles. WSMT 2, 4, and 5 made longer distance movements to the south and to the east of the bay (Fig. 1c). WSMT 2 was very active, moving close to the shore during the night, whereas it spent a long period in deep waters coming up to the surface briefly on multiple occasions right in front of an elephant seal colony at Twin Canyons (Fig. 1b). Spatial use analysis indicated three core use regions for WSMT 2, two in front of two large seal colonies close to the shore (Fig. 2c) and another $8.41 \mathrm{~km}^{2}$, in deep water away from the shore (Fig. 2d).

WSMT 4 travelled around the shore of GI toward the Outer Islet on the southern end of the island. When it reached this point, it turned to the west $3.53 \mathrm{~km}$ where we lost contact with it at 10:08 am of the following day (Fig. 1c). The total distance travelled by this shark was $66.4 \mathrm{~km}$. Spatial use analysis showed that this adult remained in a core area $17.36 \mathrm{~km}^{2}$ in front of the northeast bay (Fig. 2e). WSMT 5 travelled along the east coast of the bay parallel to coast heading south throughout for a period of $24 \mathrm{~h}$. When it reached Punta Doble (Fig. 1b), close to the southern end of GI, it moved $3.34 \mathrm{~km}$ to the east of the island. The female then moved to the shore and started to head north until contact was lost at $1.98 \mathrm{~km}$ east of the island. The total distance travelled by this shark was $54.9 \mathrm{~km}$. Spatial use analysis showed that this adult showed two core use regions, one an area of $23.25 \mathrm{~km}^{2}$ in front of the northeast bay and the other on the southeast side of the island (Fig. 2f). Overall, this study showed that white sharks have a positive correlation $\left(r^{2}=0.82 ; p<0.05\right)$ between total length and space use at GI, which is the smaller sharks had smaller core areas than the larger ones. 
Table 2 White sharks tagged in Guadalupe Island, Mexico

\begin{tabular}{|c|c|c|c|c|c|c|c|}
\hline No. & Date tagging & Size $(\mathrm{cm})$ & Sex & No. & Date tagging & Size $(\mathrm{cm})$ & Sex \\
\hline 1 & October 22, 2008 & 442 & 0 & 31 & September 30, 2010 & 350 & $?$ \\
\hline 2 & October 22, 2008 & 500 & q & 32 & October 06, 2010 & 350 & $\widehat{0}$ \\
\hline 3 & October 22, 2008 & 457 & $\hat{0}$ & 33 & October 24, 2010 & 300 & 0 \\
\hline 4 & October 22, 2008 & 400 & q & 34 & October 16, 2010 & 250 & q \\
\hline 5 & October 22, 2008 & 426 & 0 & 35 & September 13, 2010 & 350 & 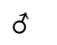 \\
\hline 6 & October 23, 2008 & 500 & 0 & 36 & October 06, 2010 & 250 & 운 \\
\hline 7 & October 24, 2008 & 502 & 0 & 37 & October 06, 2010 & 390 & 0 \\
\hline 8 & November 01, 2008 & 400 & 0 & 38 & September 06, 2011 & 200 & 0 \\
\hline 9 & November 01, 2008 & 200 & q & 39 & September 21, 2011 & 200 & $\widehat{0}$ \\
\hline 10 & December 06, 2008 & 508 & q & 40 & October 14, 2011 & 400 & q \\
\hline 11 & December 06, 2008 & 411 & 0 & 41 & September 12, 2012 & 250 & 0 \\
\hline 12 & October 11, 2009 & 400 & $\widehat{0}$ & 42 & September 24, 2012 & 250 & 0 \\
\hline 13 & October 13, 2009 & 500 & 0 & 43 & October 23, 2012 & 500 & q \\
\hline 14 & October 22, 2009 & 350 & q & 44 & October 30, 2012 & 400 & 0 \\
\hline 15 & September 10, 2009 & 450 & $q$ & 45 & October 21, 2012 & 330 & 0 \\
\hline 16 & September 07, 2009 & 450 & q & 46 & October 24, 2012 & 400 & q \\
\hline 17 & October 01, 2009 & 450 & q & 47 & October 23, 2012 & 500 & q \\
\hline 18 & September 26, 2009 & 400 & 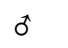 & 48 & October 21, 2012 & 330 & $0^{\star}$ \\
\hline 19 & October 17, 2009 & 400 & q & 49 & October 20, 2012 & 400 & q \\
\hline 20 & September 15, 2009 & 400 & $\widehat{0}$ & 50 & November 01, 2012 & 420 & q \\
\hline 21 & October 25, 2009 & 462 & \% & 51 & September 14, 2013 & 400 & 0 \\
\hline 22 & August 29, 2009 & 441 & 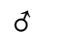 & 52 & October 14, 2014 & 570 & \% \\
\hline 23 & August 29, 2009 & 400 & $\widehat{0}$ & 53 & October 14, 2014 & 500 & q \\
\hline 24 & August 29, 2009 & 300 & $\widehat{0}$ & 54 & October 15, 2014 & 300 & 0 \\
\hline 25 & August 30, 2009 & 310 & 0 & 55 & October 21, 2014 & 400 & q \\
\hline 26 & August 30, 2009 & 300 & 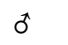 & 56 & October 21, 2014 & 300 & q \\
\hline 27 & November 05, 2009 & 500 & q & 57 & October 28, 2014 & 430 & q \\
\hline 28 & November 04, 2009 & 500 & q & 58 & October 29, 2014 & 300 & 0 \\
\hline 29 & October 15, 2010 & 450 & \% & 59 & October 29, 2014 & 490 & \% \\
\hline 30 & October 13, 2010 & 300 & 0 & 60 & November 2, 2014 & 520 & 운 \\
\hline
\end{tabular}

Summary of number, ID, date of tagging, name, sizes and sex, ${ }^{\star}=$ Male, $\uparrow=$ Female, $?=$ Undetermined

\section{Vertical movements}

The juveniles made shallow dives as they remained close to shore. WSMT 1 preferred shallow waters at night (Fig. 3a), spending $74 \%$ of the night between 10 and $30 \mathrm{~m}$ (Fig. 4a). During the day, 60 \% of WSMT 1's diving oscillations were between 40 and $70 \mathrm{~m}$. WSMT 1 swam in water with temperatures between 10 and $22{ }^{\circ} \mathrm{C}$ with an average of $18.1^{\circ} \mathrm{C}$ appearing to favor warmer waters, spending $40 \%$ of the time in water between 20 and $21^{\circ} \mathrm{C}$ (Fig. 5a). WSMT 3 behaved similar to WSMT 1, spending more time in shallower waters at night (Fig. 3c), with the depths of the dives ranging from 10 to $19.9 \mathrm{~m}$ (Fig. 4c). WSMT 3 spent $50 \%$ of the time in water temperatures between 20 and $21^{\circ} \mathrm{C}$ (Fig. 5c).

The adults made deeper dives. WSMT 2 reached a depth of $200 \mathrm{~m}$ during the day several times (Fig. 3b).
During the night, WSMT 2 spent $71 \%$ of the time between 70 and $90 \mathrm{~m}$. During the day, $55.8 \%$ of the diving oscillations were between 160 and $220 \mathrm{~m}$ (Fig. 4b). WSMT 2 experienced a temperature range from 9 to $21{ }^{\circ} \mathrm{C}$, appearing to favor cooler waters, spending $56 \%$ of the time in waters with temperatures less than $12{ }^{\circ} \mathrm{C}$ (Fig. 5b). Internal temperature did not show predation events, although the elevation of stomach temperature of $17{ }^{\circ} \mathrm{C}$ above ambient temperature recorded for WSMT2 (Fig. 3b) was broader than the maximum reported $\left(14.3^{\circ} \mathrm{C}\right)$ from adult white sharks by Goldman [14]. WSMT 4 showed a similar preference for $10-50 \mathrm{~m}$ waters at night and day although it did the deepest dive during the day (Fig. 3d). During night and day, most of WSMT 4's diving oscillations were between 40 and $49.9 \mathrm{~m}$ (Fig. 4D). WSMT 4 stayed between 19 and $19.9^{\circ} \mathrm{C}$ 

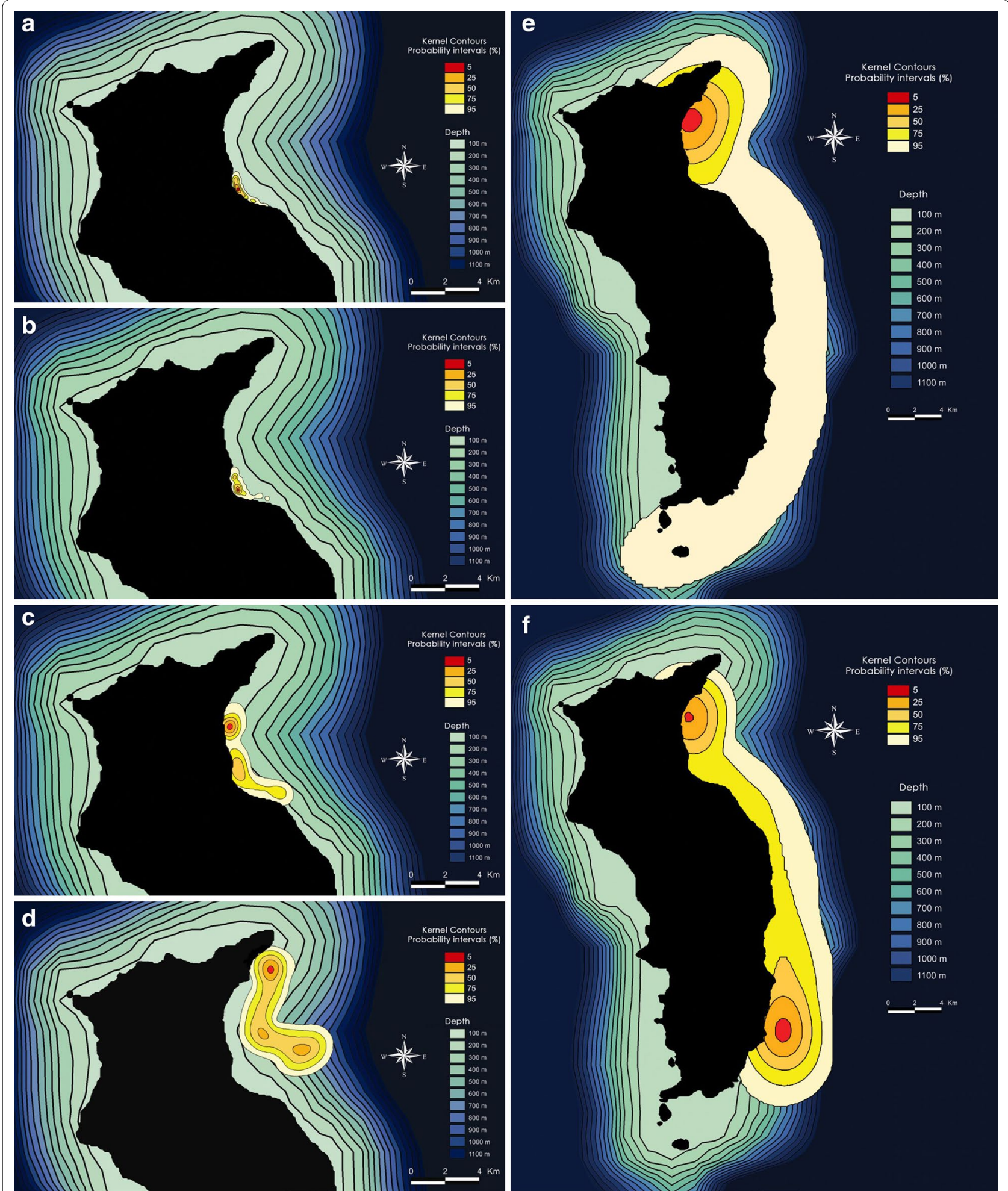

Fig. 2 Space utilization by white sharks shown with kernel densities. They are color-coded with a $50 \%$ probability (pale orange) and $95 \%$ (white). The spatial use of the juveniles WSMT1 and WSMT3 is indicated in (a) and (b); the utilization of adult WSMT2 on successive days in (c) and (d), and adults WSMT4 and WSMT5 in (e) and (f), respectively 

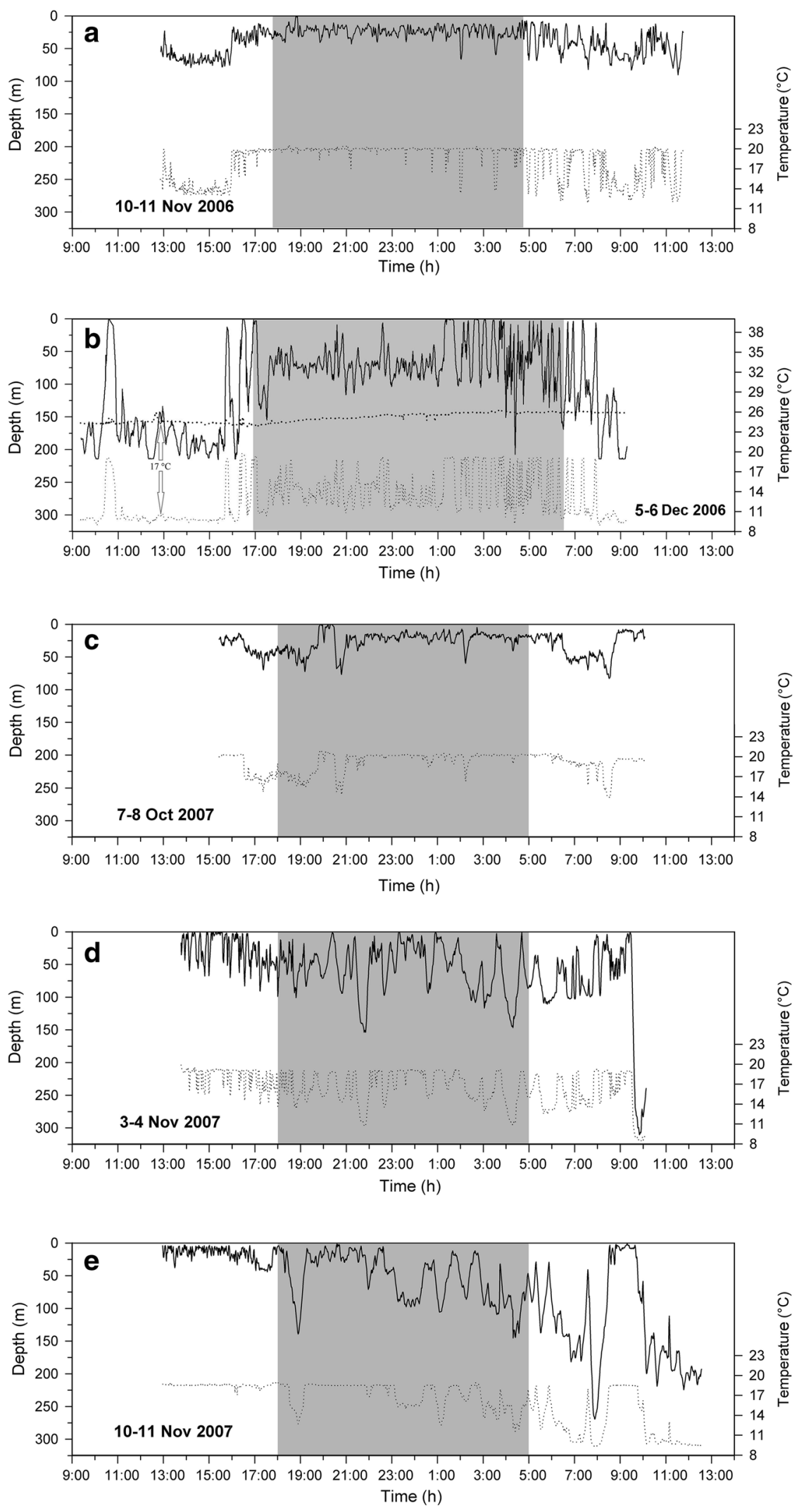
(See figure on previous page.)

Fig. 3 Vertical movements of five white sharks. a WSMT1, b WSMT2, cWSMT3, d WSMT4, e WSMT5. Night-time indicated by stippling. Stomach temperature (dark dotted line) of WSMT2 and corresponding water temperature (pale dotted line) plotted over time in (b). The red arrow shows the difference between surrounding water temperature and internal temperature of the shark

(25\%) most of the time with a second peak from 18 to $18.9{ }^{\circ} \mathrm{C}(18 \%)$ (Fig. $5 \mathrm{~d}$ ). WSMT 5 began a series of diving oscillations between 0 and $50 \mathrm{~m}$ for $5 \mathrm{~h}$ after tagging. During the night, it made dive oscillations between 11 and $138 \mathrm{~m}$. During the following day, the shark went to the maximum depth of $265.9 \mathrm{~m}$ for that tracking period and started a series of diving oscillations between the surface and $224 \mathrm{~m}$ (Fig. 3e). During the night, the shark spent a great amount of time between 10 and $40 \mathrm{~m} \mathrm{(39 \%}$ of the time). In the daytime, it spent most of the time in waters less than $50 \mathrm{~m}$ (Fig. 4e). This adult experienced a broad temperature range from 9.2 to $19.4{ }^{\circ} \mathrm{C}$, staying

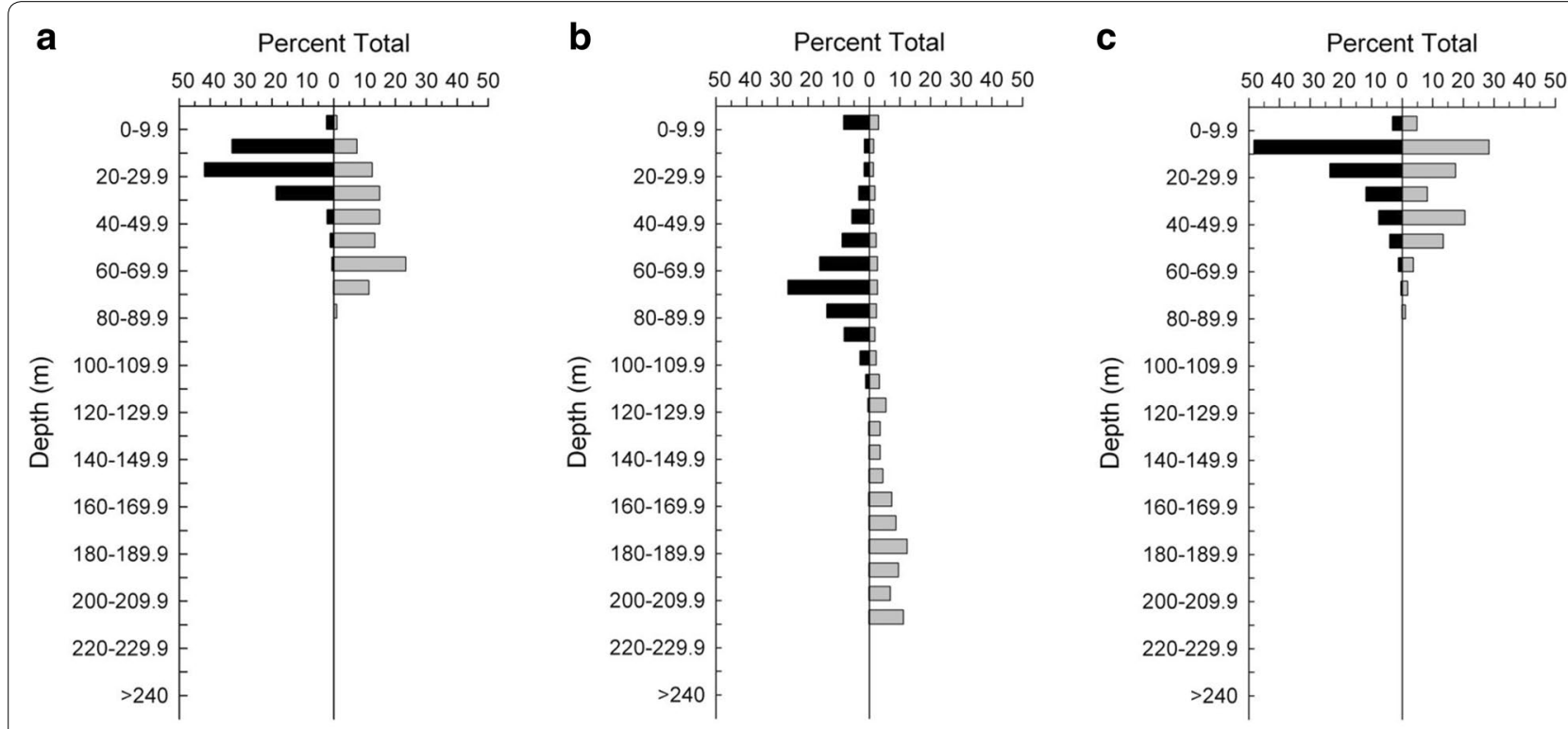

d

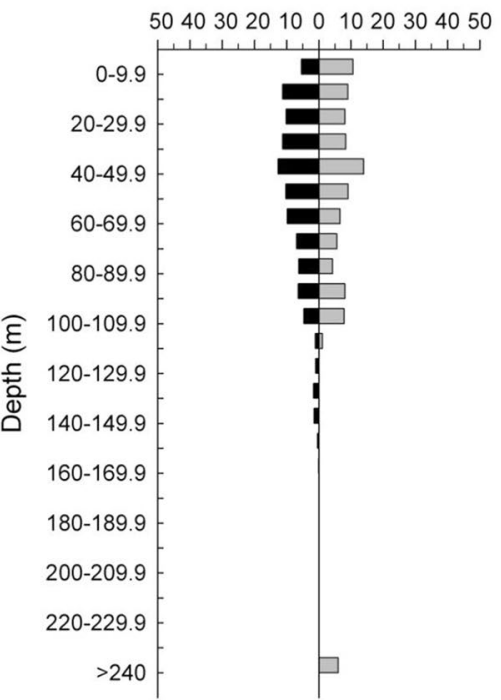

e

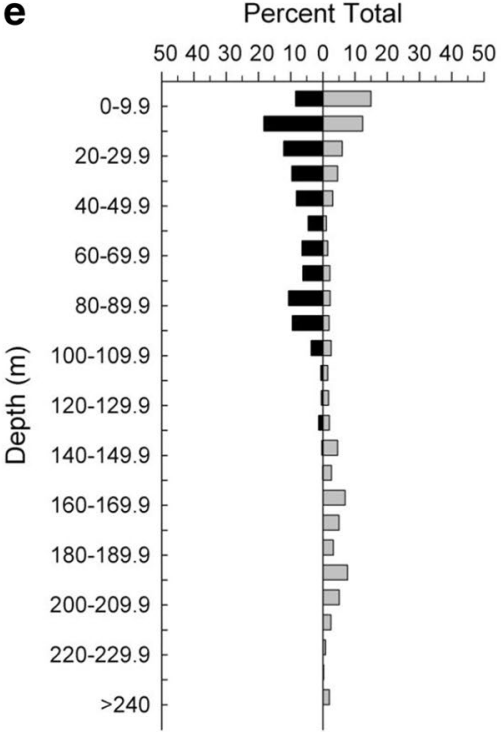

Fig. 4 Percentages of total number of measurements of different depths recorded for five great white sharks. Nighttime indicated by black bars and daytime by gray bars. a WSMT1, b WSMT2, c WSMT3, d WSMT4, e WSMT5 


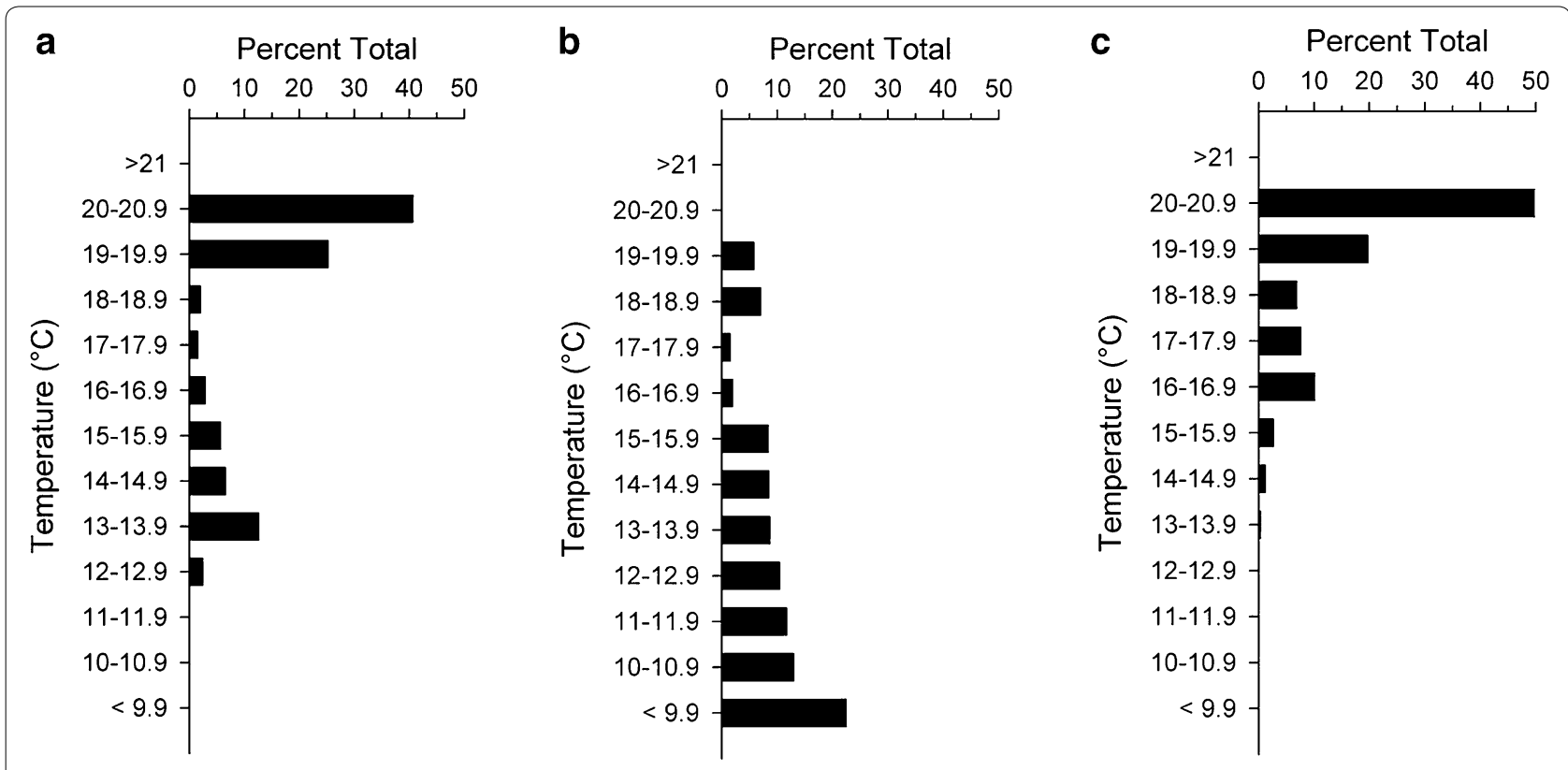

d

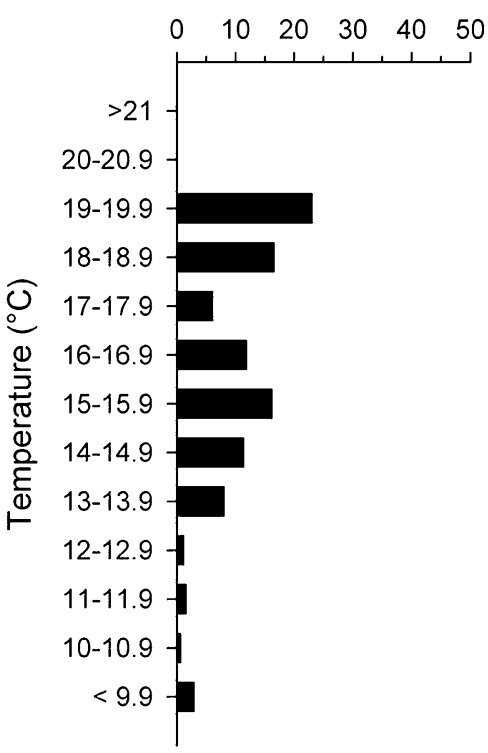

e Percent Total

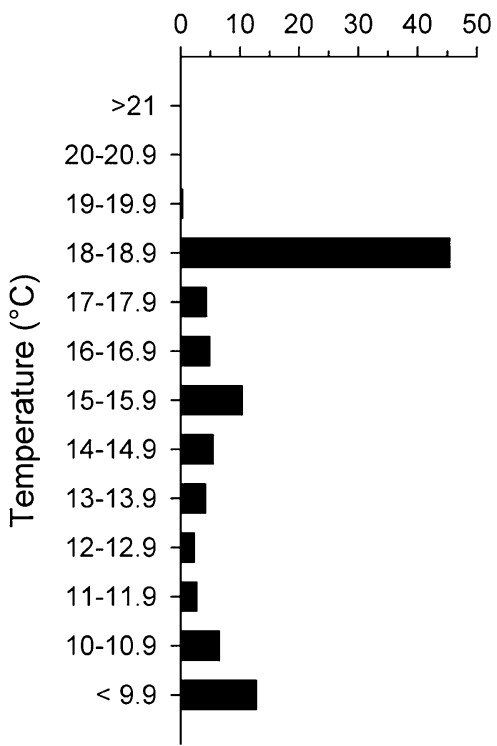

Fig. 5 Percentages of total number of measurements of different temperatures recorded in five white sharks. a WSMT1, b WSMT2, cWSMT3, d WSMT4, e WSMT5

most of the time between 18 and $18.9{ }^{\circ} \mathrm{C}(45.4 \%)$ with a bimodal distribution below this interval (15-15.9 and $<9.9^{\circ} \mathrm{C}$ ) (Fig. 5e).

Juveniles and adults exhibited a similar diurnal dive pattern, in that they remained near the surface throughout the night and made deeper dives during the day. However, the adults swam in deeper waters and hence could make deeper dives ( $t$ test; $p<0.008$ ) (Fig. 6a). Temperatures experienced by both age classes also showed a significant difference $(t$ test; $p<0.001)$ in that juveniles remained in warmer waters (from 14 to $20{ }^{\circ} \mathrm{C}$ ) while in adults remained in colder waters (from 9 to $20{ }^{\circ} \mathrm{C}$ ) (Fig. 6b).

\section{Seasonality}

The timing of shark visitation to GI differed between the life stages. Female and male juveniles were recorded throughout the year (Fig. 7), and some of them (WS36, 

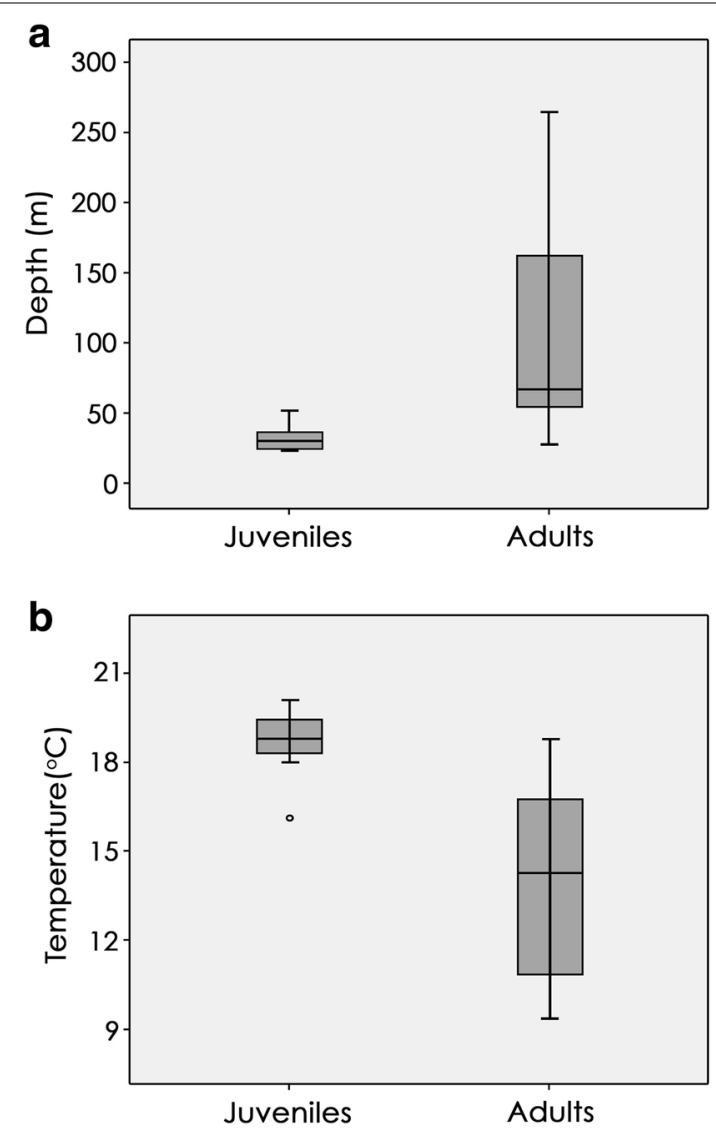

Fig. 6 Habitat preferences of white sharks at Guadalupe Island. a Depth preferences of juveniles and adults, $\mathbf{b}$ temperature preferences of juveniles and adults
WS54 and WS58) stayed intermittently from 12 to 14 months (Fig. 8). One juvenile (WS26), which remained at GI for 9 months, was detected along the west coast of the USA in Palos Verdes, California (Fig. 8).

The subadults were present most of the year, except from April to June (Fig. 7). Some of the subadults migrated to other locations. Subadult WS25 was tagged in GI in 2009, and the same year it was detected off California in Año Nuevo and Tomales. In 2010, it spent some time in Año Nuevo, Tomales, and Oregon. By 2011, the subadult returned to GI from August to December and was detected back in California from December to April 2012. The subadult male WS37 was detected from October to December 2010 in GI, and in July 2011 it was detected in Año Nuevo and Tomales Bay. Subadult female WS40 was detected from October to the end of December 2011 in GI, and by February 2012 it was detected in Año Nuevo, in Tomales Bay in March and at South Farallon Island in April. Subadult female WS50 departed GI in February 2013, and it was detected 1 month later at Año Nuevo (Fig. 8).

In the case of the adults, females were recorded from August to February while males were recorded from July to March. The maximum number of individual adult females recorded during the peak months was in October (9), November (10), and December (9). For males, it was October (13), November (12), and December (11). Adults have not been recorded at GI during the months of April, May or June (Fig. 7). The only adult tagged in GI that was detected in other location was WS8. This adult male was detected in Hawaii from July 10-16 in 2009 (Fig. 8).

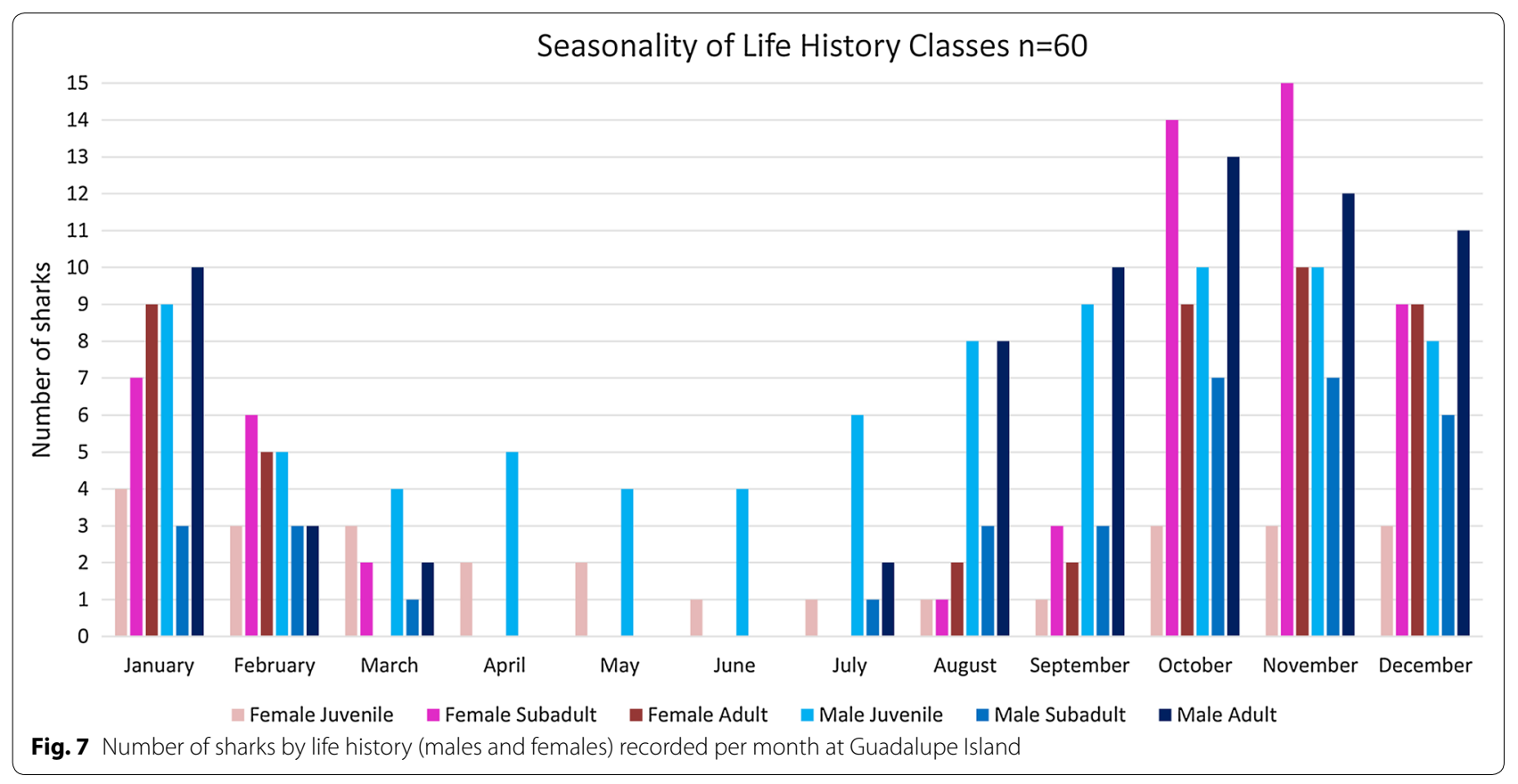




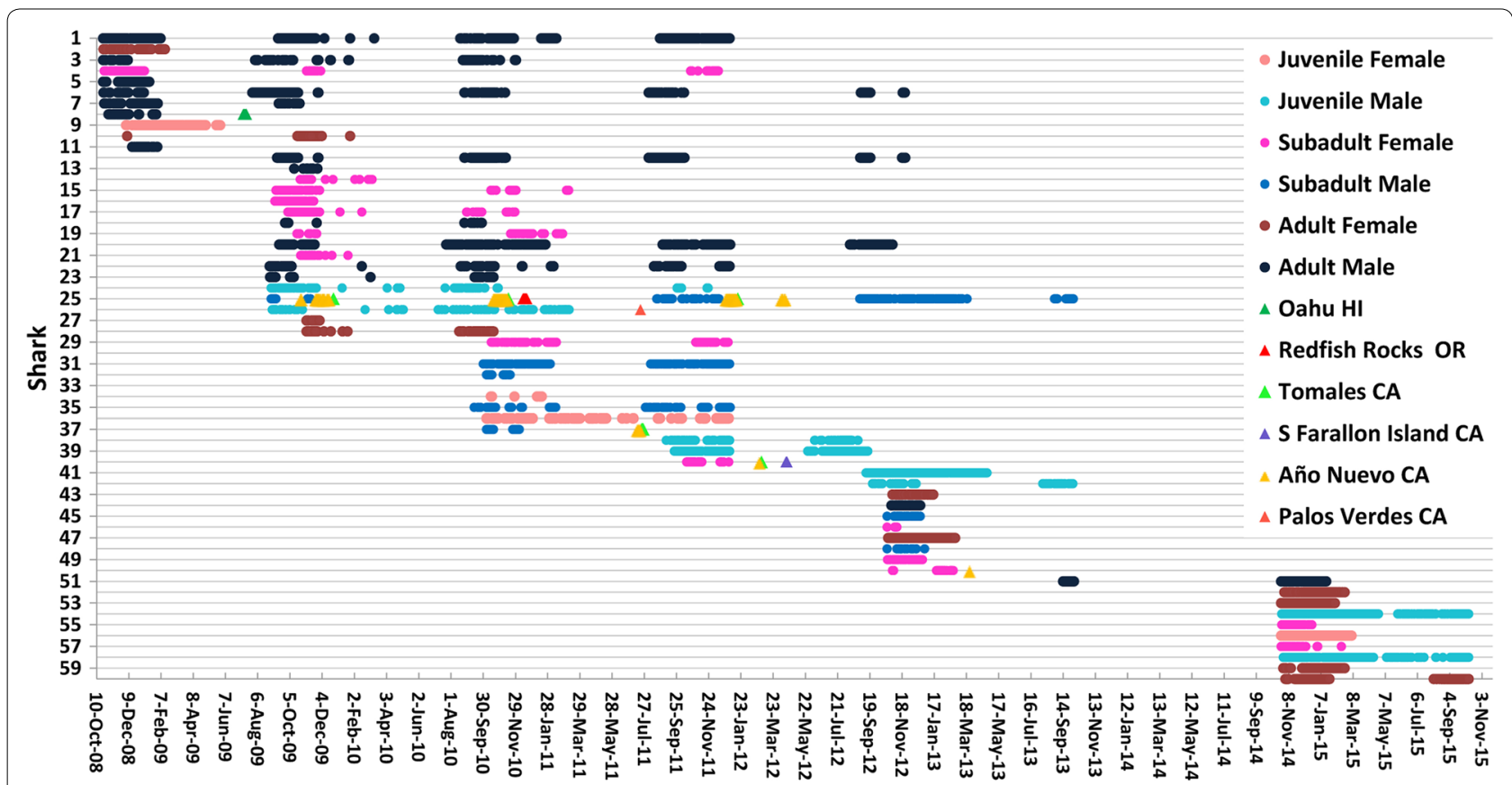

Fig. 8 Attendance of 60 white sharks at Guadalupe Island and the United States of America. Each color-coded symbol represents a detection; the colored circles are at Guadalupe Island and other colored symbols at other locations. Locations: CA California, OR Oregon, HI Hawaii

\section{Discussion}

\section{Movements and habitat use}

The WSMT 3 (180 cm TL) was the smallest white shark on record at GI. The smallest total length recorded in previous observations from 1999 to 2005 was $250 \mathrm{~cm} \mathrm{TL}$ [4]. The behavior of the juveniles, WSMT1 and WSMT 3, was similar. Both sharks patrolled very close to the coast during day and night, presenting small core use regions in a constrained area to the south of the bay (Figs. 2a, b). The depth preference patterns of the adults were for deeper waters, showing a significant difference in the depth preferences between juveniles and adults $(t$ test; $p<0.008$ ) (Fig. 6a). Temperatures experienced by both age classes also showed a significant difference $(t$ test; $p<0.001)$ in that juveniles remained in warmer waters (from 14 to $20^{\circ} \mathrm{C}$ ) while adults remained in colder waters (from 9 to $20{ }^{\circ} \mathrm{C}$ ) (Fig. 6b). This preference differential could be related to their thermoregulation capabilities. Small sharks can possibly loose more heat because of their larger surface area to volume ratio compared with larger sharks. The smallest juvenile (WSMT 3) was able to spend some time in waters between 13 and $16{ }^{\circ} \mathrm{C}$ during vertical excursions, although that temperature range represents less than $6 \%$ of the overall time. Dewar et al. [15] reported that a YOY in California Bight was able to spend up to $80 \mathrm{~min}$ in waters at $9{ }^{\circ} \mathrm{C}$ although most of the time observed (89\%) the shark remained between 16 and $22{ }^{\circ} \mathrm{C}$. The previous study suggests that thermal inertia and absolute heat production will be less for smaller great white sharks, explaining the findings. Also, conductive heat loss would be more important for small fishes, which possess greater surface area per unit volume [16]. Another explanation could be that juveniles may be avoiding the larger adults by staying close to the shore. Ecotourism operators have reported juvenile sharks attacked by adults and have observed small sharks bearing scars. Alternatively, the juveniles could remain close to shore to feed on prey abundant in shallow waters, such as bat rays (Myliobatis californica). In addition, the juveniles showed patterns (shallow excursions) during the night that could be related to feeding (Fig. 3a, c). There are a number of diurnal migrators present in GI surface waters at night that are potential prey for juvenile white sharks including squid (Onychoteuthis banksi, O. borealjaponica and Dosidicus gigas), two types of mackerel (Scomber japonicus and Auxis thazard), sardines (Sardinops carulea), flying fish (Cypselurus californicus) and anchovies [17].

Adult sharks, WSMT4 and WSMT5, presented core use regions in front of NES colonies in the northeast bay (17.36 and $9.17 \mathrm{~km}^{2}$, respectively). Goldman and Anderson [18] found larger individuals swam within particular areas around the Farallon Islands, whereas smaller individuals did not restrict their movements in the same 
manner. They suggested that despite the high frequency of predation on NES in the fall, most of the shark's movements were probably related to their search for these preys. In GI, the small individuals may restrict their movements to specific areas, whereas adults did not. A possible explanation for greater habitat ranges presented by adult white sharks in GI could be because of the differences in the dimensions of both islands. South Farallon Islands (FI) is $38,768 \mathrm{~km}^{2}$, while GI size is six times greater $\left(243,988 \mathrm{~km}^{2}\right)$. While pinniped densities per area are greater in the FI [18], the relatively small size of the island allows the sharks to swim shorter distances to patrol for them. WSMT2 remained in the northeast bay during five different manual tracks (one track of $24 \mathrm{~h}$ ), and all the core use regions were found in front of NES colonies. Interestingly, WSMT2 was tracked only in December when the NES arrive in winter along the west coast of Baja California, Mexico [19]. WSMT2 made a number of diving oscillations from $220 \mathrm{~m}$ (Fig. 3b) to the surface in the vicinity of NES colonies, behavior that could be related to the search of this specific prey. According to Le Boeuf and Crocker [20], the diving pattern of the northern elephant seal is in part an adaptation for avoiding encounters with predators, such as white sharks. By swimming faster when they are on the continental shelf, surfacing for shorter intervals, and long duration dives in the range of 200-600 m, these animals may avoid predation. Off the coast of GI, water clarity is often $25-30 \mathrm{~m}$, thereby increasing the detectability of white sharks by its prey in shallow water. Water depth, however, increases dramatically to $>1000 \mathrm{~m}$ within $5 \mathrm{~km}$ of the shoreline at GI, and white sharks may be utilizing these greater depths to remain undetected while stalking prey [21]. In addition, a pinniped may be particularly vulnerable to underwater attack. A shark stalking a seal from underneath can position itself directly below it before launching a sudden vertical attack. This hypothesis of predatory events in deep waters in GI has been supported with an AUV from Woods Hole Oceanographic Institution [21]. In this study, white sharks were observed to approach, bump and bite the AUV at depths of 36-90 m, thereby providing direct evidence of white shark predatory behavior at depth.

At Guadalupe Island, most of the attacks in December that have been witnessed were inflicted on pregnant NES females [22], possibly because their condition makes them an easier target (less mobile), and they have a greater amount of fat. Robinson et al. [23] found that because the post-molting migration coincides with fetal development, NES females had higher overall mean mass and energy gain $\left(264.6 \pm 58.6 \mathrm{~kg}\right.$ and $\left.3864.1 \mathrm{~kJ} \mathrm{~g}^{-1}\right)$ than during the winter post-breeding migration $\left(75.4 \pm 21.6 \mathrm{~kg} 1321.2 \mathrm{~kJ} \mathrm{~g}^{-1}\right)$.

\section{Seasonality}

In this study, we recorded for the first time juvenile white sharks smaller than $2.5 \mathrm{~m}$ TL in GI and have provided new information on their seasonal movements, behavior and habitat utilization at the island. The apparent residency of juvenile white sharks in GI all months of the year suggests that this region is an important habitat for this life-history stage (Figs. 7, 8). In Mexico, Sebastian Vizcaino Bay appears to be an important pupping area in the summer and is known as an aggregation site of YOY white sharks [24]. Weng et al. [25] found that a YOY (male $156 \mathrm{~cm} \mathrm{TL}$ ) moved $700 \mathrm{~km}$ from The Southern California Bight to Vizcaino Bay making incursions into offshore areas. This leads to the speculation that juveniles may explore, and such behavior could lead individuals to discover a new preferred aggregation site over time, perhaps a site like GI. The smallest juveniles tracked for a long period with coded transmitters during this study were $200 \mathrm{~cm}$ TL (WS 9, WS 38 and WS 39). The presence and permanency of these small individuals give credence to the hypothesis of GI as a secondary nursery area and that it could represent one of the "offshore island habitats" that the pups visit after they reach a size of $200 \mathrm{~cm}$ [26].

In the case of subadults, it is not known how or when they recruit to adult aggregation sites or how they learn to make seasonal migrations offshore. In our study, we recorded four subadults (WS25, WS37, WS 40 and WS 50) that moved between GI and the California coastline, one of them making the migration several times (WS25) (Fig. 8). The only tagging results that previously documented connectivity between these two aggregations correspond also to a subadult female $(366 \mathrm{~cm} \mathrm{TL})$ [27], giving more credence to the hypothesis of Domeier [28] who mentioned that the subadult stage may be a source of mixing between the two metapopulations of adults (Central California and GI). There are long periods of absence of data from the receivers, probably due to the subadults performing their first offshore migration. Domeier [28] tracked a $3.15 \mathrm{~m}$ TL subadult (one of the smallest he tagged in GI) and inferred that this male had recently arrived at the aggregation, showing an atypical offshore migration, in that they are not temporally or spatially synchronized with those of adult males. We suggest juveniles move to close islands, such as GI, and return to the nursery areas where they were born before they are sexually mature and able to carry on with a large offshore migration.

Of the 60 tagged individuals in this study, 25 were adults. From these, six male white sharks have been recorded at GI for three or more seasons, six were detected for two seasons (three males and three females), and 12 were recorded for just one season (five males and seven females). Unfortunately, the absence of detections 
could be related to either the drain of the battery in the transmitter, or the loss of the transmitter altogether. Adult males were present from July to March and females from August to February. The timing of seasonal presence and site fidelity recorded at GI are similar to those observed at the Farallon Islands [29] and previous studies with photo-identifications at GI [4]. The majority of the world's known white shark aggregations are centered on dense pinniped concentrations, suggesting that concentrated food supply may be the primary reason these aggregations occur [4]. Although we did not find direct evidence of predation (rise in the internal temperature stomach), there are several records of predation events on NES in GI [22]. Jaime et al. [30] described the feeding and migratory habits of the white shark from GI, using stable isotopic analysis of dermis. Their analysis reflected the importance of pinnipeds as prey in GI adding credence to the hypothesis of the movements of adult white sharks in GI potentially associated with foraging and the seasonal cycles of NES. In the northern hemisphere, the reproductive period for NES starts in early December and ends in midMarch, and most pregnant females begin arriving in midDecember [31]. The white sharks may have been targeting the NES because of their higher fat content and their need of a high energy supply before they depart from the island. As white sharks approach maturity, they begin annual (in the case of males) and biannual (in the case of females) migrations between offshore habitats and two known adult aggregation sites, one located off central California in the USA and the other off Guadalupe Island, Mexico.

\section{Conclusions}

Existing white shark research in GI has focused almost exclusively on the adult component of the population. This study provides new insights into juvenile and subadult white shark behavior. It also provides further evidence that GI is perhaps a secondary nursery ground for white sharks in Mexico. This information is crucial not only to improve our understanding of white shark biology in Mexican waters, but also for their long-term conservation and management plans. The data collected in our study suggest that juveniles arrive to GI from nursery grounds on the mainland after they have reached $180 \mathrm{~cm}$ TL; then, they remained on the island up to 14 months. In addition, they start their first offshore migrations when they are subadults, coming back to their nursery grounds and GI before they reach maturity. While they are in GI, they stay close to the shore and in shallow water to avoid adults, feeding on demersal prey and species that perform nocturnal migrations such as squid and mackerel. It is argued that the distribution of the large white sharks in GI is controlled by the availability of NES and that adult white sharks look for this prey in deep waters during the day in the vicinity of the seal colonies, taking advantage of the great visibility of GI waters. It is also possible that white sharks take advantage of pregnant NES in GI before they perform their offshore migration or their visit to pupping grounds to give birth in CA and Baja California in the case of females.

\section{Abbreviations \\ USA: United States of America; GI: Guadalupe Island; NES: Northern elephant seal; FI: Farallon Island.}

\section{Authors' contributions}

MHP participated in the design of the experiment, performed the data analyses, conducted all fieldwork, drafted the manuscript, and created the figures. APK and FGM conceived the study, obtained funding for the project, and assisted to draft the manuscript. AA obtained funding for the project, conducted fieldwork, and helped to draft the manuscript. All authors read and approved the final manuscript.

\section{Author details}

1 Pelagios Kakunjá, A.C., La Paz, Baja California Sur, Mexico. ${ }^{2}$ Fins Attached, 19675 Still Glen Drive, Colorado Springs, CO 80908, USA. ${ }^{3}$ Biotelemetry Laboratory, Department of Wildlife, Fish, and Conservation Biology, University of California, Davis, One Shields Avenue, Davis, CA 95616, USA. ${ }^{4}$ Instituto Politécnico Nacional, Centro Interdisciplinario de Ciencias Marinas (CICIMAR), Av. IPN s/n, C.P. 23096 La Paz, B.C.S., Mexico.

\section{Acknowledgements}

We thank those PIs from the acoustic networks maintained in the USA for reporting data when our tags were detected: Tomales Point, Farallon Islands and Año Nuevo Island-Dr. Block and Dr. Jorgensen; Palos Verdes-Dr. Castleton; Redfish Rocks, Oregon-Dr. Calvanese and Hawaii-Dr. Holland. This research was funded by Alianza WWF-TELCEL, International Community Foundation, Fins Attached, The Watermen Project, Grupo Bursatil Mexicano, The Guadalupe Island Conservation Fund, Pfleger Institute of Environmental Research, Instituto Politecnico Nacional (COFAA, EDI), lemanya Oceanica, Shark Trust, Shark Diver, Aquarium of the Pacific, Vallartech Diving and Chedraui. Field work was greatly facilitated through courtesies extended to us by personnel of the University of California, Davis, Centro Interdisciplinario de Ciencias Marinas (CICIMAR), Secretaria de Marina, Comision de Areas naturals Protegidas (CONANP), Island Conservation (GECI), Horizon Charters, Islander Charters, Nautilus Explorer, Solmar V, Club Cantamar, MN Andrea Lynn, and local fishermen from Guadalupe Island. This research was conducted under the next Scientific Research Permits from Mexico: Secretaria del Medio Ambiente y Recursos Naturales (SGPA/DGVS/04053/07); Comisión Natural de Áreas Naturales Protegidas (F00. RNO. RBIG.-154/07 and F00. RNO. RBIG.-166/07); Secretaria de Gobernación (DICOPPU/211/1827/07).

\section{Competing interests}

The authors declare that they have no competing interests.

Received: 14 January 2016 Accepted: 30 June 2016

Published online: 16 July 2016

\footnotetext{
References

1. Galván-Magaña F, Hoyos-Padilla EM, Navarro-Sermet CJ, Márquez-Farías F. Records of white shark, Carcharodon carcharias, in the Gulf of California, Mexico. Mar Biodiversity Rec. 2010;3:e111.

2. Galván F, Nienhuis H, Klimley P. Seasonal abundance and feeding habits of sharks of the lower Gulf of California, Mexico. Bull Calif Fish Game. 1989;75:74-84

3. McCosker JE, Lea RN. White shark attacks in the eastern Pacific Ocean: an update and analysis. In: Klimley AP, Ainley DG, editors. Great white sharks: the biology of Carcharodon carcharias. San Diego: Academic Press; 1996. p. 419-34.
} 
4. Domeier M, Nasby-Lucas N. Annual re-sightings of photographically identified white sharks (Carcharodon carcharias) at an eastern Pacific aggregation site (Guadalupe Island, Mexico). Mar Biol. 2007;150:977-84.

5. Hubbell G. Using tooth structure to determine the evolutionary history of the white shark. In: Klimley AP, Ainley DG, editors. Great white sharks: the biology of Carcharodon carcharias. San Diego: Academic Press; 1996. p. 9-18.

6. Klimley AP. The predatory behavior of the white shark. Am Sci. 1994:82:122-33.

7. Klimley AP, Pyle P, Anderson SD. The behavior of white sharks and their pinniped prey during predatory attacks. In: Klimley AP, Ainley DG, editors. Great white sharks: the biology of Carcharodon carcharias. San Diego: Academic Press; 1996. p. 175-91.

8. Bruce BD, Bradford RW. Habitat use and spatial dynamics of juvenile white sharks, Carcharodon carcharias, in eastern Australia. In: Domeier ML, editor. Global perspectives on the biology and life history of the white shark. Boca Raton: CRC Press; 2012. p. 225-53.

9. Pierson MO. Breeding behavior of the Guadalupe fur seal, Arctocephalus townsendi. In: Croxall JP, Gentry RL, editors. Status, biology, and ecology of fur seals. NOAA Tech Rep NMFS51; 1987. p. 83-94.

10. Klimley AP, Le Boeuf BJ, Cantara KM, Richert JE, Davis SF, Van Sommeran S, Kelly JT. The hunting strategy of white sharks (Carcharodon carcharias) near a seal colony. Mar Biol. 2001;138:617-36.

11. Klimley AP, Kihslinger RL, Kelly JT. Directional and non-directional movements of bat rays (Myliobatis californica) in Tomales Bay, California. Environ Biol Fish. 2005;74:79-88.

12. Hooge PN, Eichenlaub WM, Solomon EK. Using GIS to analyze animal's movements in the marine environment. Gustavus: Alaska Biological Science Centre, US Geological Survey; 2000.

13. Seaman DE, Powel RA. An evaluation of the accuracy of Kernel density estimators for home range analysis. Ecology. 1996;77:2075-85.

14. Goldman KJ. Regulation of body temperature in the white shark, Carcharodon carcharias. J Comp Physiol B. 1997:167:423-9.

15. Dewar H, Domeier M, Nasby-Lucas N. Insights into young of the year white shark, Carcharodon carcharias, behavior in the Southern California Bight. Environ Biol Fish. 2004;70:133-43.

16. Block BA, Finnerty JR. Endothermy in fishes: a phylogenetic analysis of constraints, predispositions, and selection pressures. Environ Biol Fish. 1994;40:283-302.

17. Gallo-Reynoso JP. Factors affecting the population status of Guadalupe fur seal, Arctocephalus townsendi (Merriam, 1897), at Isla de Guadalupe, Baja California, México. United States: Ph.D. Thesis. University of California, Santa Cruz; 1994

18. Goldman K, Anderson SD. Space utilization and swimming depth of white sharks, Carcharodon carcharias, at the South Farallon Islands, Central California. Environ Biol Fish. 1999;56:351-64.

19. Reiter J, Pankenk J, Le Boeuf BJ. Female competition and reproductive success in northern elephant seals. Anim Behav. 1988;129:670-87.
20. Le Boeuf BJ, Crocker DE. Diving behavior of elephant seals: implications for predator avoidance. In: Klimley AP, Ainley DG, editors. Great white sharks: the biology of Carcharodon carcharias. San Diego: Academic Press; 1996. p. 193-205.

21. Skomal GB, Hoyos-Padilla EM, Kukulya A, Stokey R. Subsurface observations of white shark Carcharodon carcharias predatory behaviour using an autonomous underwater vehicle. J Fish Biol. 2015:87:1293-312.

22. Hoyos-Padilla ME. Movement patterns of the white shark (Carcharodon carcharias) at Guadalupe Island, Mexico. Mexico: PhD Thesis, Centro Interdisciplinario de Ciencias Marinas, Instituto Politécnico Nacional; 2009.

23. Robinson PW, Costa DP, Crocker DE, Gallo-Reynoso JP, Champagne CD. Foraging behavior and success of a mesopelagic predator in the Northeast Pacific Ocean: insights from a data-rich species, the northern elephant seal. PLoS ONE. 2012;7:e36728.

24. Santana-Morales O, Sosa-Nishizaki O, Escobedo-Olvera MA, OñateGonzález EC, O'Sullivan JB, Cartamil D. Incidental catch and ecological observations of juvenile white sharks, Carcharodon carcharias, in western Baja California, Mexico. In: Domeier ML, editor. Global perspectives on the biology and life history of the white shark. Boca Raton: CRC Press; 2012. p. 187-98.

25. Weng KC, O'Sullivan JB, Lowe CG, Winkler CE, Dewar H, Block BA. Movements, behaviour and habitat preferences of juvenile white sharks Carcharodon carcharias in the eastern Pacific. Mar Ecol Prog Ser. 2007:338:211-24.

26. Klimley AP, Anderson SD, Pyle P, Henderson RP. Spatio-temporal patterns of white shark (Carcharodon carcharias) predation at the South Farallon Islands, California. Copeia. 1992;1992:680-90.

27. Jorgensen S, Chapple TK, Anderson S, Hoyos-Padilla EM, Reeb C, Block BA. Connectivity among white shark coastal aggregation areas in the Northeastern Pacific. In: Domeier ML, editor. Global perspectives on the biology and life history of the white shark. Boca Raton: CRC Press; 2012. p. 159-67.

28. Domeier ML. A new life-history hypothesis for white sharks, Carcharodon carcharias, in the Northeastern Pacific. In: Domeier ML, editor. Global perspectives on the biology and life history of the white shark. Boca Raton: CRC Press; 2012. p. 199-223.

29. Klimley AP, Anderson SD. Residency patterns of white sharks at the South Farallon Islands, California. In: Klimley AP, Ainley DG, editors. Great white sharks: the biology of Carcharodon carcharias. San Diego: Academic Press; 1996. p. 365-73.

30. Jaime-Rivera M, Caraveo-Patiño J, Hoyos-Padilla EM, Galván-Magaña F. Feeding and migration habits of white shark Carcharodon carcharias (Lamniformes: Lamnidae) from Isla Guadalupe inferred by analysis of stable isotopes $815 \mathrm{~N}$ and $813 \mathrm{C}$. Rev Biol Trop. 2014;62(2):637-47.

31. Le Boeuf BJ, Laws RM. Elephant seals: an introduction to the genus. In: Le Boeuf BJ, editor. Elephant seals: population ecology, behavior and physiology. Berkeley: University of California Press; 1994. p. 1-26.

\section{Submit your next manuscript to BioMed Central and we will help you at every step:}

- We accept pre-submission inquiries

- Our selector tool helps you to find the most relevant journal

- We provide round the clock customer support

- Convenient online submission

- Thorough peer review

- Inclusion in PubMed and all major indexing services

- Maximum visibility for your research

Submit your manuscript at www.biomedcentral.com/submit 